than 36 weeks, separately or together, are of serious import has been confirmed and amplified by recent studies. During the last six weeks of gestation the foetus grows rapidly, but the placenta does not. The most important measure of placental function is thus the continuing growth of the foetus. Purely placental parameters would be useful if their variation were to precede demonstrable foetal damage. A number have been studied.

For several years we have used output of oestriol in 24-hr urine. This substance is finally elaborated by trophoblastic enzymes from dehydroepiandrosterone produced in the foetal suprarenal. Examples of the use of this to foretell slow growth of the foetus will be given and some pitfalls discussed, also its significance in conditions inimical to the foetus such as maternal hypertension or pre-eclamptic toxaemia.

More recently we have tried to use the output of oxytocinase (aminopepsidase) produced by trophoblast alone. A series is presented to confirm norms for this and to compare it with oestriol output in complicated pregnancies. The mean level of oxytocinase output varies widely from case to case, so it is even more important to establish a trend over several weeks than for oestriol. Since foetal tissues are not involved, early trouble in the foetus is not revealed, but what can be interpreted as early placental failure has been demonstrated. As in all similar recent studies this is often unconfirmed since, if in doubt, the obstetrician may terminate pregnancy as soon as the foetus is mature enough to risk this and the biochemistry is only one factor in making his decision.

\section{Trypsin and Chymotrypsin Determinations in Human Duodenal Aspirate under the Influence of Continuous Secretin-pancreozy- min Stimulation as an Aid in the Diagnosis of Pancreatic Disease}

D. M. GOLDBERG AND K. G. WORMSLEY (Sheffield)

The output of trypsin and chymotrypsin was measured in the duodenal aspirate of 46 patients free of known pancreatic disease or with normal pancreatic function as defined by volume, bicarbonate, and amylase response. The data from this group were compared with those obtained in 16 patients with objectively defined pancreatic disease and three patients with gastric ulcer and defective pancreatic function. In all, 150 tests were conducted, most subjects having their enzyme output measured under different regimes of stimulation, all hormones being given by continuous intravenous infusion and results expressed as milligrams enzyme per 30 minutes.

With all pancreozymin tests, $0 \cdot 25$ units secretin $/ \mathrm{kg} /$ hour was used to promote background flow. Insufficient data were obtained to allow evaluation of dose rates of 8 units pancreozymin $/ \mathrm{kg} /$ hour and 2 units secretin $/ \mathrm{kg} /$ hour. Some overlap between the two groups was found when 4 units pancreozymin $/ \mathrm{kg} /$ hour was used, but separation was almost complete when the dose of pancreozymin was raised to 16 units $/ \mathrm{kg} /$ hour. Better discrimination was achieved with trypsin than with chymotrypsin, although the occasional case in the second group gave low values for the latter only with some forms of stimulation.

It is recommended that for routine purposes trypsin be measured during infusion of 0.25 units secretin and 4 units pancreozymin $/ \mathrm{kg} /$ hour. Under these conditions an output $>100 \mathrm{mg} / 30$ minutes indicates normal pancreatic function and $<50 \mathrm{mg}$ abnormal pancreatic function. Where intermediate values are obtained, the dose of pancreozymin should be increased to 16 units $/ \mathrm{kg}$, and it may be worth while to measure chymotrypsin output as well in order to define the status of the patient more precisely.

\section{The Effect of Instant Cirrhosis on Rat Serum Proteins}

C. H. W. HORNE AND R. N. MACSWEEN (Glasgow)

Cirrhosis of the liver is known to be accompanied by marked alterations in the levels of serum proteins. Only in experimental cirrhosis, however, is there a ready opportunity to study serum protein levels before, during, and after the production of cirrhosis.

Cirrhosis was produced in rats using the method of McLean, McLean, and Sutton (1969). Serum samples were obtained at weekly intervals before, during, and after treatment with carbon tetrachloride and sodium phenobarbitone, and also from animals treated with either preparation alone. Using a radial immunodiffusion technique the levels of four serum proteins, namely, albumin, slow $\alpha_{1}$ globulin, transferrin, and $\gamma_{2}$-globulin, were determined and the concentrations expressed as a percentage of a pooled normal rat serum sample. All animals were necropsied and macroscopic and microscopic proof of the presence or absence of cirrhosis was obtained. Striking alterations in the levels of all four serum proteins were observed. The significance of these으 findings was discussed.

Reference

McLean, E. K., McLean, A. E. M., and Sutton P. M. (1969). Brit.J.exp. Path., 50, 502-506.

Effect of Severe Hypoxia on DNA-labelling
Pattern of Blood Eosinophils

G. HUDSON AND K. CHIN (Department of $\overrightarrow{0}$ Haematology, University of Sheffield)

The emergence pattern of DNA-labelled $\vec{\omega}$ eosinophil granulocytes into the circu-o lation following administration of tritiated $\overline{0}$ thymidine has been used to follow up an earlier finding that for the first week or more of exposure to severe hypoxia, or guinea-pigs show a marked peripheral $\stackrel{\oplus}{V}$ eosinophilia accompanied by depletion of eosinophil numbers in the bone marrow.

Intraperitoneal injections of tritiated thymidine in doses of 1 microcurie pergram of body weight were given to guineapigs of approxiamely $400 \mathrm{~g}$ body weight at two-hour intervals over eight hours. At $\overrightarrow{0}$

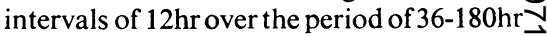
after the first injection, blood smears were: taken and prepared for autoradiography. In four animals normal conditions were maintained throughout. Six animals were similarly maintained but at a barometric pressure of about 3.5 torr (equivalent to that at $20,000 \mathrm{ft}$ altitude); in three the hypoxia was commenced $16 \mathrm{hr}$ before theo믈 injections, while in three it was commenced immediately afterwards.

Significantly, labelled eosinophils wereㅁํ․ first seen in the controls at $72 \mathrm{hr}$ and by $156 \mathrm{hr}$ over $90 \%$ of blood eosinophils were labelled. In the hypoxic animals, labelled eosinophils were detected at $36 \mathrm{hr}$; there after the percentage of labelled cells in theô blood was significantly higher than in the controls until 120 hours. There was noo evidence of a difference in labelling pattern between animals in which hypoxia was $\frac{7}{0}$ commenced before or after the injections.

The results are consistent with a reduc- $N$ tion in the minimum transit time through the postmitotic pool of eosinophils in the marrow during the earlier stages of exposure to severe hypoxia.

Anti-cancer Organization

C. G. PANTIN (Noble's Hospital, Douglas) There are advantages in working in an $\frac{T}{-}$ island with a small and rather static population. People cannot stray in from adjoin- $\stackrel{\mathbb{Q}}{\square}$ ing territory. When elsewhere one would $\vec{\Phi}$ work with samples, on the island one can 